DOI 10.32726/2411-34170-2019-1-67-91

УДК $1 ; 94$

\title{
ВлАдимиР Романов
}

\section{Первая мировая война и трансформация глобального мышления академического сообщества США}

\begin{abstract}
Аннотачия. В статье анализируется вклад академического сообщества США в разработку идеологического каркаса нового мирового порядка после окончания Великой войны. Данное сообщество представляло собой своеобразный конгломерат многочисленных научных и образовательных корпорачий и авторитетных ученых. При всем разнообразии подходов, большинство американских интеллектуалов разделяло базовые принципы вильсонизма, а сам президент В. Вильсон регулярно привлекал ученых к внешнеполитическому планированию. Первая мировая война не только расширила горизонты мышления американской политико-академической элиты, но и закрепила в умонастроениях ее представителей новый формат концепции «американской исключительности».
\end{abstract}

Ключевые слова: Первая мировая война, новый миропорядок, вильсонизм, американская исключительность, политико-академическое сообщество США, Лига Наций.

$\Pi^{2}$ ервая мировая война стала одним из переломных этапов исторического развития цивилизации. Под ее влиянием изменились не только глобальная политическая и социально-экономическая конфигурация, но и интеллектуальный ландшафт большинства стран. Отметим, например, появление принципиально новых подходов к оценкам перспектив международного сотрудничества. Импульс войны нашел отражение в новых научных дисциплинах и институциональных представлениях. Мировой конфликт нанес серьезный ущерб гуманистической концепции мышления XIX в. и поставил под сомнение положение мыслителя в обществе [Первая мировая война и судьбы... с. 638; The Intellectual...p. 4]. Да и у самих интеллектуалов (особенно в западных странах), формирующих и высказывающих те или иные суждения, наметился крен в так называемый постмодерн. Это проявилось в утрате традиционных теоретических, моральных и политических ориентиров. Очень скоро постмодерн, по точному замечанию А.В. Дьякова, «превратится в девиз интеллектуалов, обнаруживших, что больше нет ни ориентиров, ни авторитетов, а значит, нет и ответственности». Логическим завершением данного тренда стало широкое распространение убеждения, что интеллектуалы и не должны формулировать никаких принципов, их «обязанность состоит в подрыве всех и всяческих принципов» [Дьяков].

Сведения о6 авторе: РОМАНОВ Владимир Викторович - профессор Тамбовского государственного университета (ТГУ) имени Г.Р. Державина, доктор исторических наук; vvromanov@mail.ru. 
Американским интеллектуалам под воздействием Первой мировой войны пришлось осваивать еще и новый формат глобального мышления. Соединенные Штаты, стремительно ворвавшиеся в круг великих держав, нуждались в основательном научном сопровождении внешнеполитического курса президента Вудро Вильсона, заявившего в апреле 1917 г. о стремлении «сделать мир безопасным для демократии».

Особую роль при реализации данной задачи сыграло академическое сообщество США. Объединявшее в тот период прежде всего преподавателей высших учебных заведений, оно не являлось каким-либо единым и жестко структурированным социальным институтом. Скорее это был конгломерат различных научных и образовательных корпораций, каждая из которых обладала, как правило, собственным интеллектуальным климатом. Тем не менее знакомство даже с отдельными точками зрения, имевшими распространение в этой среде, позволяет выявить определенный вектор умонастроений авторитетного сегмента американского общества.

Обращение к взглядам академической элиты Соединенных Штатов периода Первой мировой войны интересно еще и тем, что взаимоотношения ученых и власти, сложившиеся в ту пору, стали основой для создания в США политико-академического комплекса. Под этим термином понимается довольно устойчивое, хотя и неформальное, объединение ученых и представителей политического истеблишмента страны, в котором первые играли роль «мозгового центра». Окончательное оформление такого комплекса, по мнению В.Ф. Петровского, произошло только к середине XXв. [Петровский, с. 8] Однако во время пребывания у власти администрации В. Вильсона уже наметилось существенное сближение ученых и политиков. Став первым в истории США президентом, пришедшим в Белый дом с профессорской кафедры, Вильсон предпринял довольно успешную попытку сделать академическое сообщество постоянным фактором в процессе принятия различных решений. Чаще всего ученые выступали в те годы в роли официальных или неофициальных экспертов по отдельным вопросам внешней политики США.

Показательно, что до начала мировой войны среди интеллектуалов было широко распространено ожидание, что администрация сумеет обновить некоторые базовые принципы американской внешней политики, дополнив их рядом идеалистических компонентов. Так, профессор Висконсинского университета Пол Рейнш, которого В. Вильсон назначил послом в Китай, всегда выступал как убежденный сторонник доктрины «открытых дверей». Однако, беседуя с президентом накануне своего отбытия в Пекин, П. Рейнш делал акцент не столько на экономическом аспекте американской политики, сколько на ее образовательном и культурном наполнении. Самое серьезное внимание, по его мнению, следовало уделять поддержке политических преобразований в Китае по «западным образцам» [Reinsch, p. 217-219]. Такая же точка зрения была высказана и профессором Стэндфордского университета Дэвидом Джордоном, который в письме к Вильсону призвал его отказаться от традиций «дипломатии доллара». Эта политика, как указывал ученый, является «наиболее опасным наследием прошлой администрации» [D.S. Jordon to WW]. 
Профессор истории Кларкского университета (штат Массачусетс) Джордж Блейксли на страницах The North American Review (декабрь 1913 г.) затронул вопрос о необходимости модернизации доктрины Монро. По его мнению, в старом понимании эта доктрина подразумевала «моральное подчинение» латиноамериканских государств Соединенным Штатам. В частности, он ссылался на точку зрения авторитетных общественных деятелей Чили. Так, редактор одной из ведущих газет страны доктор Перес Санто в беседе с Д. Блейксли прямо заметил: «Мы не хотим никакого отца». В новых условиях, когда государства Латинской Америки приобрели авторитет на международной арене, их народы, по словам профессора, уже не могли соглашаться с прежним смыслом доктрины Монро. Исходя из этого, Блейксли обращался к необходимости «панамериканизации доктрины на новых принципах». Он предложил заключить межамериканское арбитражное соглашение, которое объединило бы все государства континента для достижения принципиально новой политической цели - стабильных правительств и порядка в регионе. При этом он противопоставил Европу, объединяющуюся для войны, и Америку, которая должна объединиться для мира [The North American Review].

Любопытно и мнение, высказанное на этот счет Джэкобом Г. Голландером, профессором Университета Джонса Гопкинса. Он еще со времен Т. Рузвельта выполнял различные поручения Белого дома в Доминиканской республике. В апреле 1913 г. Д.Г. Голландер направил на имя В. Вильсона меморандум, в котором критиковал подходы предыдущих администраций как к Доминиканской республике, так и к латиноамериканскому региону в целом. Он, в частности, обращал внимание президента на «серьезнейшую опасность» попыток некоторых американских предпринимателей использовать в корыстных целях потенциал дипломатии США. «Сегодняшняя ситуация, как никогда ранее, требует отказаться от такой практики», - резюмировал Голландер [J.H. Hollander to WW].

Мировая война подтолкнула не только американское руководство, но и академическое сообщество к размышлениям о более существенных внешнеполитических проблемах. Поляризация общественного мнения США по вопросу об американской стратегии в условиях европейского конфликта не могла не проявиться и в позициях различных ученых.

Уже в августе 1914 г. президент Гарвардского университета Чарльз Элиот изложил В. Вильсону свое мнение в связи с началом войны. В нескольких письмах, отправленных на имя президента, Ч. Элиот совершенно недвусмысленно сформулировал предложение присоединиться к странам Антанты для совместной борьбы против агрессоров: «Возможно ли в настоящее время Соединенным Штатам выступить с предложением о создании наступательного и оборонительного союза между Британской империей, США, Францией, Японией, Италией и Россией для наказания Австро-Венгрии и Германии за те ужасы, которые они творят, путем установления бойкота этих двух стран всем остальным миром - на суше и на море?» Аргументируя свою точку зрения, Элиот отметил, что США не могут оказаться в стороне от европейского конфликта, поскольку речь идет о «защите цивилизации от варварства» и об «установлении и поддержании в будущем федеративных отношений и мира среди европейских народов». «Неужели 
ради такой цели и в виду изменившихся условий народ Соединенных Штатов не одобрил бы отказ от заветов Вашингтона о том, что Соединенные Штаты должны стоять в стороне от европейских осложнений?»

Ч. Элиот высказал и свои предварительные соображения относительно основ нового миропорядка, который должен быть установлен после окончания войны. По сути, он указал на целесообразность формирования союза государств, который сумел бы, используя международные войска, в будущем противостоять любым межгосударственным конфликтам. При этом Элиот полагал, что непременным условием урегулирования должен стать «отказ всех европейских участников от всяких стремлений к насильственному расширению своей территории» [Ch. Eliot to WW, Aug. 6]. Точка зрения президента Гарвардского университета, видимо, подтолкнула Белый дом к серьезным размышлениям. Неслучайно эти письма стали предметом специального рассмотрения на заседании кабинета министров. Однако в условиях августа 1914 г. и В. Вильсон, и его ближайшие внешнеполитические советники, опираясь на общественные настроения, высказались за политику нейтралитета [Kuehl, p. 173-174].

Опубликованные документы из архива президента показывают, что такая позиция Белого дома первоначально нашла поддержку у подавляющего большинства представителей академических кругов. Они одобряли не только правительственный курс на нейтралитет, но и действия президента по посредничеству между воюющими группировками. Показательно, например, письмо, направленное президенту деканом школы богословия Чикагского университета Шэйлером Мэтьюзом 18 августа 1914 г. Выступая в поддержку политики В. Вильсона, он предлагал предпринять новые энергичные шаги для убеждения мирового сообщества в необходимости всеобщего договора, который закрепил бы международные санкции против любого агрессора [S. Mathews to WW].

С самого начала войны в академическом сообществе США нашли достаточно широкое распространение антигерманские настроения. Об этом говорит, например, участие американских ученых в «войне манифестов» [См.: Мировые войны... с. 125-128; Дмитриев, с. 202-210.]. Начало этой войне было положено воззванием «К культурному миру», которое было опубликовано в Германии в сентябре 1914 Г. Под ним стояли подписи 93 немецких интеллектуалов, большинство из которых были профессорами различных германских университетов. В воззвании опровергались обвинения по адресу Германии в развязывании войны и в зверствах немецких солдат на оккупированных ими территориях. Одновременно в документе отстаивалась «спасительная ценность» той войны, которую ведут Германия и ее союзники. Опираясь на расовые аргументы, немецкая профессура, например, подчеркивала: «Менее всего имеют право разыгрывать роль защитников европейской цивилизации те, кто заключил союз с русскими и сербами и являют миру позорное зрелище, натравливая монголов и негров на белую расу». Ответы на данное воззвание появились во многих государствах Европы. Резкий отпор немцам был дан и в Соединенных Штатах.

Автором американского меморандума, опубликованного 4 ноября 1914 г., стал Сэмюэль Г. Черч, президент института Карнеги в Питтсбурге [Тексты воззвания... с. 33]. 
Представляя в некоторой мере все академическое сообщество США, он, конечно, не забыл указать на сохранявшиеся у американцев симпатии к немецкому народу. Тем не менее уже первый тезис Черча показывал, на чьей он стороне. По мнению автора меморандума, европейский конфликт по своей природе являлся войной «между добрыми и злыми силами». А ответственность за начало войны он однозначно возложил на Австро-Венгрию, которую полностью поддерживала и контролировала в каждом шаге Германия. При этом С.Г. Черч особо указал на вину немецких профессоров, которые не только «помогали вселять в умы ваших молодых людей доктрину, что война неизбежна», но и всячески пропагандировали национальную исключительность Германии, «предназначенной поддерживать свое превосходство грубой силой оружия». Завершая свой ответ, Черч высказал важное предположение о судьбе послевоенного мира: «Может быть, по воле Провидения из этой войны родится идея, что благо человечества выше блага отдельных рас, и что правительство, которое не усвоит себе эту идею, должно погибнуть» [Там же, с. 7, 18, 26-27].

Позицию С.Г. Черча поддержали тогда и другие ученые США. Среди них, например, президент Колумбийского университета Н.М. Батлер, известный экономист Т. Веблен и др. [Первая мировая война: Исторический очерк, с. 127].

Позднее антигерманская позиция ряда ученых привела их к размышлениям относительно той роли, которую должны играть Соединенные Штаты в условиях войны. Например, профессор Колумбийского университета Дж. Бир в одной из своих статей, опубликованных журналом The New Republic, настойчиво убеждал соотечественников, что американская «политика эгоистичной отчужденности от событий в Европе означала абсолютное игнорирование той ответственности, которую обязано нести каждое государство перед человечеством». Война, с точки зрения Дж. Бира, являлась прямым столкновением германского милитаризма с демократией, олицетворяемой Великобританией. Он соглашался с утверждением, что «Антанта сражается за Америку», и указывал на очевидные «моральные погрешности» нейтралитета Соединенных Штатов. Выходом из данного положения Бир считал немедленное сближение с Великобританией и оказание ей всесторонней помощи во имя создания в будущем прочного союза англоговорящих стран [The New Republic, vol. 5, № 55, p. 62-64]

Однако в американской академической среде было представлено и противоположное суждение о войне. Профессор психологии Гарвардского университета Г. Мюнстерберг, например, в 1914-1915 гг. пытался активно противостоять проантантовским симпатиям в американском обществе, вступая в публичные дискуссии с авторитетными общественными деятелями США (например, Т. Рузвельтом) [Münsterberg The War... Idem. The Peace... T. Roosevelt to H. Münsterberg]. Пользуясь старым знакомством с Вильсоном, гарвардский профессор не раз направлял письма и в Белый дом. При этом Г. Мюнстерберг подчеркивал, что его позиция отражала точку зрения значительной части американского общества, прежде всего - германо-американской и ирландско-американской общин. Поддерживая призывы администрации к нейтралитету, он отмечал, что на деле полного нейтралитета все же не было. По мнению профессора, Соединенные Штаты были настолько подвержены английскому влиянию через прес- 
су или торговлю, что легко могли превратиться «в британскую провинцию». Отстаивая важность равноудаления США от воюющих сторон, Мюнстерберг указывал на очевидный «антантовский крен» финансово-экономических отношений Америки и Европы. Он высказывал опасение, что победа в войне одной из сторон «будет означать унижение противоположной». Следовательно, заключал Мюнстерберг, нельзя идти на поводу «фанатичных выступлений», звучавших, например, из уст Ч. Элиота. Лучше всего, убеждал он В. Вильсона, использовать любой благоприятный психологический момент для осуществления посредничества. Предлагал Мюнстерберг и принципы возможного, по его мнению, мирного урегулирования. Среди них: взаимный отказ от территориальных изменений в Европе, выплата компенсации Бельгии и нейтрализация морей [H. Münsterberg to WW].

Об активности Г. Мюнстерберга не раз писал в министерство иностранных дел российский посол в Вашингтоне Ю.П. Бахметев. По его информации, профессор всячески стремился убедить В. Вильсона в целесообразности прекращения американских поставок в Великобританию. Поскольку без этого англичане и их союзники не смогли бы, с точки зрения Мюнстерберга, долго вести войну, то были бы созданы благоприятные условия для американского посредничества. При всех сомнениях относительно возможности реализации данной схемы, Ю. Бахметев обращал внимание на «чувствительность» президента к предложениям, высказанным Мюнстербергом. Вильсон, отмечает посол, может не устоять «против соблазна приобрести вечную славу умиротворителя Европы» [АВПРИ. Ф. 170. Оп. 512/1. Д. 341. Л. 105-106].

Конечно, оценивая точку зрения Г. Мюнстерберга, нельзя сбрасывать со счета немецкое происхождение профессора и, видимо, его участие в прогерманской пропагандистской кампании на территории США, которой руководил тогда Б. Дернбург. Однако его позиция в целом все же не выходила за рамки «прогерманского нейтрализма» [Keller, p. 87]. При этом отдельные замечания Мюнстерберга вполне отражали опасения ряда американских интеллектуалов, считавших, что только жесткий нейтралитет помог бы Соединенным Штатам держаться над европейским конфликтом и в итоге занять место мирового арбитра.

Нельзя обойти вниманием и первые размышления американских ученых по поводу глубинных причин, которые привели к войне. На страницах популярного еженедельника The New Republic в 1914-1915 гг. не раз публиковались письма читателей, затрагивавших данную проблему.

Уже в ноябре 1914 г. профессор С.Н. Паттен указывал на национальные противоречия, ставшие, по его мнению, важнейшим источником начавшегося конфликта. Он писал, что в Европе к началу XX в. сформировались три очевидных центра: латинские народы; народы Центральной Европы, находящиеся под контролем Германии и Австро-Венгрии; народы Восточной Европы, тяготеющие к России. Следует ли, задавался вопросом профессор, считать в таком случае войну германской агрессией? Или, может быть, Германия всего лишь начала борьбу за отстаивание своих интересов в Центральной Европе? Столкновений такого рода, заключал С. Паттен, в будущем можно 
избежать лишь с помощью интеграционных процессов, которые объединили бы всю Европу.

Точка зрения американского профессора нашла поддержку у его английского коллеги из Лондонского университета Г. Уэлласа. В январе 1915 г. на страницах The New Republic было опубликовано его письмо, в котором он полностью одобрил идею создания «Соединенных Штатов Европы». При этом он заметил, что «такое объединение должно было быть создано не в результате военной победы какой-либо группы держав, а только по согласию всех европейских стран с концепцией межгосударственного права в рамках федеральной организации» [The New Republic, vol. 1, № 2, p. 22; vol. 1, № 9, p. 24].

Специалисты в области международного права попытались в этот период предложить свои суждения относительно возможностей сохранения мира после окончания войны. Один из них, А.У. Спенсер, убедительно доказывал, что старая концепция «баланса сил», определявшая долгое время существование «европейского концерта», оказалась бы совершенно бесполезной в новых условиях. Он полагал, что новый миропорядок следует поддерживать лишь через санкции международного права. А. Спенсер подробно рассмотрел теоретические и практические аспекты таких санкций, обосновав перспективы использования политической, экономической, военной и моральной силы в международных отношениях [The American Journal... p. 45-46].

На начальном этапе войны американские ученые попытались разработать и более детальные проекты послевоенного мироустройства. Приведем только один пример, показывающий широту суждений академической элиты на этот счет. В самом начале 1915 г. Вильсон получил письмо от своего старого школьного друга Р. Дэбни, который проинформировал президента, что профессор права Вирджинского университета Р.К. Майнор подготовил к печати «чрезвычайно интересную книгу». Может быть, суждения Р. Майнора и покажутся несколько утопичными, писал Дэбни, но все равно международное сообщество «должно двигаться в этом направлении». Профессор, как видно из письма, предложил текст Конституции международной организации, названной им «Объединенные Нации», и другие правовые документы, которые могли бы регулировать ее деятельность. За основу такой организации была взята модель Соединенных Штатов Америки [R.H. Dabney to WW]. B. Вильсон заинтересовался работой Майнора, но от конкретного обсуждения высказанных ученым соображений уклонился, сославшись на нецелесообразность публичных дебатов о мире, способных в тот период лишь «вызвать раздражение воюющих» [WW to R.H. Dabney... p. 10-11;WW to R.C. Minor... p. 18]. Позднее, в 1918 г., книга Майнора была издана [Minor].

Внимание ученых в период американского нейтралитета привлекали и конкретные действия дипломатии США. Уже упоминавшийся Ч. Элиот, например, самым тщательным образом анализировал содержание американо-германской переписки относительно «Лузитании» и подводной войны. Он высказывал В. Вильсону свои соображения по поводу аргументации, которую президенту следовало бы использовать в ответных письмах германскому руководству [Ch. Eliot to WW, July 16]. Профессор Колумбийского 
университета Джордж Керчви говорил о необходимости созыва особой международной конференции, на которой следовало бы обсудить нарушение прав нейтралов воюющими державами. Он полагал, что компромисс мог быть найден лишь в том случае, если немцы признали бы право нейтралов на «свободный и беспрепятственный проход по морю», а американцы согласились бы с признанием судов воюющих государств, на которых перевозятся военные грузы, «квазивооруженными». Завершая свой меморандум, Д. Керчви подчеркивал, что такая конференция, созванная по частному вопросу, «могла бы легко быть трансформирована в конференцию по мирному урегулированию под руководством американского президента» [G.W. Kirchwey to WW].

Как видим, многие американские ученые в 1914-1915 гг. задумывались над различными проблемами совершенствования международных отношений. Их мысль смело следовала тогда в сторону обоснования участия США не только в урегулировании европейского конфликта, но и в послевоенных действиях во имя поддержания мира.

Президент В. Вильсон внимательно отслеживал точку зрения академического сообщества. Это часто признавали и сами представители этого сообщества. Так, в августе 1916 г. профессор Принстонского университета Эдвин Конклин в письме на имя редактора The New York Times (NYT) обоснованно подчеркнул, что президент, как ни один другой из его предшественников, пытался регулярно «получать информацию от ученых и честно к ней прислушиваться» [NYT, Aug, 12, 1916].

Интерес академического сообщества к проблемам мироустройства значительно вырос в 1916 - начале 1917 г. К этому времени стало ясно, что политика нейтралитета и посредничества, проводимая официальным Вашингтоном, не достигла своих целей. Американская дипломатия так и не смогла остановить конфликт на «ничейной позиции». При этом администрация В. Вильсона оказалась не в состоянии преодолеть трудности во взаимоотношениях с ведущими европейскими державами. Германия, например, никак не отказывалась от ставки на неограниченную подводную войну, в ходе которой гибли граждане США, а Великобритания постоянно усиливала блокадные мероприятия, резко ограничивавшие возможности американской торговли.

В новой обстановке глава американской администрации стал менять акценты в своей дипломатии. Главное внимание он решил сосредоточить не столько на посредничестве в войне, сколько на перестройке самой системы международных отношений. С этой целью В. Вильсон попытался публично обосновать новую роль Америки, которая якобы вполне способна стать инициатором борьбы за «вечный мир». Это, по его мнению, имело очевидный общецивилизационный смысл и отличалось от узконациональных задач, решаемых на фронтах войны. Выступая перед Лигой по принуждению к миру 27 мая 1916 г., Вильсон впервые открыто заявил о претензиях США на особый голос в деле послевоенного урегулирования [An Address...].

Такие действия администрации не могли не стать предметом жарких общественных споров в США. Как выяснилось, Америку больше всего волновал вопрос о целесообразности отказа от изоляционистской традиции. На страницах The New York Times 
с 20 ноября по 18 декабря 1916 г. была опубликована серия статей, посвященных перспективам урегулирования европейского конфликта. Их автор скрывался за анонимной подписью Cosmos, и только впоследствии выяснилось, что это был известный американский юрист-международник, президент Колумбийского университета Николас М. Батлер.

Всего за этот период им было подготовлено шестнадцать крупных статей. Первые шесть были напечатаны с подзаголовком «Все хотят мира: Почему бы не заключить его сейчас». Остальные вышли с общим названием «Какова должна быть его основа?»

Эти материалы сразу привлекли внимание президента В. Вильсона. А уже в начале 1917 г. они при финансовой поддержке Фонда Карнеги были изданы отдельной книгой и переведены на другие языки, в том числе и на русский [См.: J.P. Tumulty to WW; E.M. House to WW; Основы...; Kuehl, p. 207-208]. Статьи получили значительный общественный резонанс, поскольку автору удалось квалифицированно представить не только фундаментальные принципы, но и болевые точки новой внешнеполитической доктрины США.

Публикации в The New York Times открывались кратким анализом ситуации, сложившейся в Европе к концу 1916 г. Автор, в частности, указывал на всеобщую подавленность от «огромности войны» и ее последствий. «Теперь ясно, - писал он, - что Германская империя и ее союзники не могут выиграть войну», а победа Великобритании и ее союзников «будет куплена... невероятно большой ценой». По его мнению, в этих условиях наибольшую актуальность приобретали два главных вопроса: как в будущем избежать подобных войн и как привести к концу все еще продолжавшийся конфликт [NYT, Nov. 20, 1916; Основы...c. 4-5]. Это были проблемы, о которых уже давно задумывалась Европа. Однако американский ученый рассуждал не так, как рассуждали в Старом Свете.

За отправную точку в разговоре о «прочном мире» Н.М. Батлер взял вильсоновский тезис об очевидной порочности военных целей воюющих государств. Все они, по его мнению, стремились либо к приобретению каких-либо экономических привилегий, либо к ограничению своих конкурентов. Подтверждение своим словам он находил, например, в решениях экономической конференции Антанты (Париж, 14-17 июня 1916 г.). Батлер полагал, что в качестве базового принципа новых послевоенных отношений следовало бы взять американскую доктрину «открытых дверей». «Союзные державы, - подчеркивал он, - имеют исключительно благоприятную возможность заложить основы прочного мира, если по окончании войны они предложат Германии и ее союзникам полное участие на равных основаниях в мировой торговле». Естественно, всеобщая реализация этой идеи, говорилось в статье, потребует не только «новых форм международной гарантии национальной безопасности», но и «нового мировоззрения» у всех народов (в том числе и у американцев) [NYT, Nov. 21, 22, 1916; Основы... с. 10-14, 15-16, 19-21].

Обозначенная точка зрения не противоречила вильсоновской внешнеполитической логике и основывалась на известном положении о равной ответственности всех евро- 
пейских держав за то соперничество, которое привело мир к войне. Вот почему статьи Н.М. Батлера, вслед за действиями американского президента, вызвали протест, например, со стороны английской общественности.

Уже 25 ноября 1916 г. один из английских читателей The New York Times, Холл Кэн, указал на принципиальные отличия в образе мысли американцев и европейцев. «Вы находитесь, - написал он на имя Cosmos'а в редакцию газеты, - вдали от тех душевных переживаний, которые создала война». Но для того чтобы говорить о мире, отметил читатель, необходимо не только знать, но и чувствовать войну. Чрезвычайно важен и другой довод Х. Кэна (его впоследствии не раз использовали европейские политики в разговорах с Вильсоном). По мнению англичанина, немедленное прекращение войны и заключение компромиссного мира означало бы «преступную, непоправимую, непростительную, слепую и ослепляющую расточительность». Такой мир, писал он, был бы «изменой по отношению к мертвым, нелояльностью по отношению к живым, подрывом авторитета государственной власти, открытым призывом к беззаконию и анархии, намеренным надругательством над принципами патриотизма и даже священными велениями религии». Поэтому материалы первых статей дали повод Кэну подозревать Cosmos'a в прогерманских симпатиях [NYT, Nov. 25, 1916; Основы... с.128-135].

Однако дальнейшие публикации в некоторой степени развеяли такую оценку. Обратившись к анализу конкретных политических условий возможного мира, Н.М. Батлер выказал понимание важнейших целей, во имя которых европейские державы вступили в конфликт. Послевоенный мир, утверждал автор статей, должен исправить ряд ошибок старой европейской дипломатии. В частности, отторжение Германией ЭльзасЛотарингии было, по его словам, «политическим преступлением», и поэтому во имя прочного мира эти территории следовало бы вернуть Франции [NYT, Nov. 27, 1916; Основы... с. 45-46].

Весьма интересны размышления Н.М. Батлера, касавшиеся России. Для западного мира и особенно для американцев, заметил он, Россия по-прежнему оставалась «бесконечно далекой страной», «страной тайны». Тем не менее по своему предназначению в современном мире она являлась мостом «между старым Востоком и новым Западом». Оценивая изменения, происшедшие в России, автор делал вывод, что Россия с каждым годом становится все более западной «в развитии ее мысли и ее внутренней политики». Поэтому, указывал он, «в интересах прочного мира Россия должна господствовать над проливами» [NYT, Nov. 28, 1916; Основы... с. 48-53].

Совсем иное, негативное отношение было у Н.М. Батлера к Германии, или, более точно, к прусскому милитаризму. Пруссия, говорилось в одной из статей, «никогда не представляла себе тевтона иначе как сражающимся» против славянина или франка, англосакса или еще кого-нибудь. Поэтому прочный мир не мог быть создан без сокрушения прусского милитаризма, без либерализации страны, без духовных перемен в самом немецком народе [NYT, Nov. 30, 1916; Основы... с. 57-64]. Таким образом, в подходах к европейским участникам войны Батлер проявил себя вполне уравнове- 
шенным экспертом. Он видел, конечно, что главная опасность для дела мира исходила из Германии, но при этом совсем не желал безоговорочной победы Антанты.

Продолжая размышлять о принципах нового международного порядка, Н.М. Батлер сделал еще один очень важный вывод: такие меры, как возвращение Франции Эльзас-Лотарингии, передача России Босфора, ограничение прусского милитаризма, могли быть лишь «результатом принуждения». Следовательно, послевоенный мир «должен бы иметь санкцию и поддержку международного права и опираться на такую определенную и сильную международную гарантию, что ни одна держава в будущем не смогла бы с легким сердцем посягнуть на него или пошатнуть его». А для этого «необходимо соглашение между всеми великими державами, включая Соединенные Штаты и Японию, относительно того, в чем состоят основные права и обязанности наций». Кроме того, для уменьшения вероятности войны следовало бы добиться договоренности о судебном разрешении всех международных разногласий. Другими словами, Батлер выступил за дальнейшее развитие международно-правового механизма, разработанного еще на Гаагских конференциях. При этом он был убежден, что более важным для дела мира являлся «дух тех народов, которые соединятся для проведения этих мер». По его мнению, для сохранения мира необходимо добиться всеобщего «интернационального миросозерцания» [NYT, Dec. 2, 4, 1916; Основы... с. 65-67, 69, 72-77].

В своих статьях Н.М. Батлер не обошел вниманием и вопрос о роли Соединенных Штатов в деле установления нового мироустройства. Его вывод был совершенно однозначен: международная конференция для выработки условий прочного мира не может пройти без Америки, поскольку США «являлись участником этой войны, участником, правда, нейтральным и против своего желания». Автор высказал убеждение, что продолжавшийся конфликт не являлся «обыкновенной войной», это было «столкновением идеалов, жизненных миросозерцаний, политических и социальных стремлений». Поэтому такая война «не могла закончиться компромиссом». Неспособность или нежелание занять определенную позицию в этом конфликте означали, по словам Батлера, «или такую умственную тупость, при которой человек неспособен понять самых важных мировых вопросов, или такую глубокую аморальность, при которой человеку безразлична судьба человечества, его свободы и его прогресса».

Автор считал, что нейтралы (в том числе США) должны бы быть за одним столом с воюющими. Однако возможное участие Соединенных Штатов в работе сообщества наций Н.М. Батлер сопроводил рядом оговорок. Он считал, что Америка, развивая отношения со всем миром, вряд ли в ближайшее время смогла бы принять на себя полный спектр международных обязанностей и международной ответственности. Причина коренится в особенностях конституционной системы США, не позволявшей использовать вооруженные силы страны без согласия законодателей, и в традиционном образе мысли американцев. Для участия США в сохранении международного порядка, писал Батлер, было бы целесообразно учредить особую область юрисдикции. «Одна юрисдикция простиралась бы на Европу и на те части Азии и Африки, которые непосредственно зависят от Европы; другая - на Америку» [NYT, Dec. 9, 1916; Основы... с. 90-98]. Обоснованием этому варианту, по мнению автора, могла быть действовавшая доктрина Монро. Таким 
образом, «прямая ответственность правительства Соединенных Штатов за применение нового международного порядка была бы ограничена пределами американских континентов и территорий, принадлежавших какой-либо из американских республик». В этой связи Батлер поднял вопрос и о выделении третьей зоны ответственности для Японии, что означало бы провозглашение «своего рода азиатской доктрины Монро» [NYT, Dec. 15, 18, 1916; Основы... с. 109-117, 121].

Данные соображения носили весьма перспективный характер. С одной стороны, их можно рассматривать как некий промежуточный вариант участия США в мировой политике, учитывавший не только популярность изоляционистских настроений американского общества, но и позицию критиков администрации со стороны республиканской партии. При этом интернационализм Н.М. Батлера отличался от вильсоновской точки зрения большим реализмом. Следует согласиться, например, с американской исследовательницей Сондрой Херман, которая писала о том, что требование «свободы рук» и разделения «сфер влияния», о чем шла речь в данных газетных публикациях, вполне напоминало известную систему «концерта» великих держав [Herman, p. 47]. Как известно, в рамках Венской системы международных отношений такой «концерт» продемонстрировал изрядную жизнеспособность.

Значительное место в размышлениях Н.М. Батлера о новом миропорядке занимала проблема санкций. Отвечая на вопрос о возможности силовых действий против нарушителей международного права, он говорил, что «применение силы в отношениях между нациями вызывало серьезные возражения». Не видел он пока и какого-либо будущего в создании международной полицейской власти для исполнения постановлений Международного суда. По его мнению, наибольшее значение в этом деле должно бы играть «общественное мнение цивилизованного мира» [NYT, Dec. 15, 1916; Основы...с. 99-107].

Суждения Н.М. Батлера относительно проблемы войны и мира, отраженные на страницах The New York Times, сумели соединить в себе несколько «потоков» американского общественного мнения рубежа 1916-1917 гг. Здесь отчетливо видна официальная «нейтралистская» позиция неприятия войны, окрашенная яркими цветами «американизма». При этом новый миропорядок выстраивался у Батлера на прочной правовой концепции, в основе которой лежал американский институционально-правовой опыт. Реалистические представления о принципах новой системы международных отношений (в частности, идея «сфер влияния») в рассмотренных статьях причудливо переплетались с идеалистическими понятиями о санкциях.

Статьи Н.М. Батлера, опубликованные в ноябре - декабре 1916 г. в The New York Times, его последующие выступления и публикации позволяют говорить о поддержке многих фундаментальных принципов вильсонизма в самых широких слоях политикоакадемического истеблишмента США. Батлер, будучи представителем республиканской партии, сумел осознать целесообразность «либерально-демократической перестройки» всей системы международных отношений после окончания мировой войны. При этом он предлагал ряд интересных корректив программы президента. В частно- 
сти, предложения Батлера относительно нескольких юрисдикций в создаваемой Лиге, вполне могли бы стать первым шагом на пути вхождения США в новое сообщество наций.

Вступление США в войну в апреле 1917 г. существенным образом сказалось на роли науки в обеспечении внешней политики страны. Наиболее значимым для Вильсона стало идеологическое обеспечение американского участия в мировом конфликте. Здесь существенный вклад внесли историки, особенно представители «новых историков», придерживавшихся, как правило, реформистских взглядов. Война чаще всего рассматривалась ими как столкновение «демократической» Антанты с «автократической и милитаристической» Германией. Следовательно, для них это была своего рода борьба за реформу миропорядка [Mayer, p. 79-80]. Поэтому многие «новые историки» активно поддержали действия администрации Вильсона.

Одним из них был Джеймс Шотуэлл, профессор истории Колумбийского университета. Именно он сразу же после вступления США в войну выступил с инициативой организации особого комитета историков для изучения ее различных аспектов. В своем университете Д. Шотуэлл создал «информационный отдел» и библиотеку, где собирались и сохранялись различные материалы по войне.

Предложение привлечь своих коллег к поддержке усилий администрации высказали также Историческая ассоциация долины Миссисипи, историки Университета штата Висконсин и др. В результате в апреле 1917 г. было создано Национальное управление исторической службы (National Board for Historical Service). Его первым руководителем стал Д. Шотуэлл. На проведенной 28-29 апреля 1917 г. конференции историков было решено, что новая организация будет заниматься публикацией в прессе исторической информации по военной проблематике, публичными лекциями, совершенствованием преподавания истории, сбором библиографии по военным темам. Словом, это была помощь правительству в деле формирования общественного мнения в поддержку внешнеполитического курса США.

Наиболее зримой работой историков стали, конечно, их публикации. Только для Комитета общественной информации, созданного администрацией Вильсона, сотрудники Управления подготовили примерно 50 памфлетов, тираж которых превышал 75 млн. экземпляров. При этом Д. Шотуэлл и его коллеги никогда не сближались с ультрапатриотическими организациями, поскольку не считали возможным для себя участвовать в джингоистской истерии или откровенно антигерманской кампании. Историки оставались сторонниками сохранения «научного уровня» в деятельности Управления. Данный подход, как справедливо отметил автор монографии о Д. Шотуэлле Г. Джозефсон, в целом отражал понимание «новыми историками» предназначения истории. Для них она была прагматической наукой, призванной помочь в понимании и объяснении настоящего [Josephson, p. 50-52, 57-63]. Позднее многие деятели Управления, в том числе и сам Шотуэлл, были приглашены к работе исследовательского бюро по подготовке американских условий мира. 
Помимо историков, пропагандистской деятельностью занимались и другие ученые США. В частности, Академия политической науки весной 1917 г. выступила инициатором проведения первой национальной конференции по вопросам внешней политики. Своей целью организаторы называли «формирование и распространение «международного духа»» в стране, информирование населения о проблемах положения в мире. За четыре дня конференции с ее трибуны выступили 140 человек, представлявших не только многочисленные университеты, но и различные общественные организации США (например, Фонд Карнеги, Лигу по принуждению к миру, Женскую партия мира и т.п.). В центре дискуссии оказалась тогда проблема создания Лиги Наций. Практически все участники говорили о крайней необходимости ее создания. В частности, общее настроение сумел точно выразить Г. Холт, один из организаторов Лиги по принуждению к миру. Он сформулировал возможные альтернативы дальнейшего развития цивилизации: после войны может произойти «либо европеизация Америки, либо американизация Европы» [The Foreign Relations... p. IX-XIV, 17-19, 45, 69]. Таким образом, ученые активно подключились к работе по трансформации общественного сознания в пользу интернационализма.

Наиболее важным практическим вкладом академического сообщества в дело подготовки официальной американской программы послевоенного миропорядка стала деятельность исследовательского бюро «Инквайри». Оно было создано по распоряжению Вильсона в сентябре 1917 г. По справедливой оценке историков, эта организация явилась не только «первым «мозговым трестом» в Америке», но и «первым случаем широкого использования правительством Соединенных Штатов талантливых ученых из самых различных областей в целях формирования американской внешней политики» [Knock, p. 140; Gelfand The Inquiry... p. XI]. Неофициальным руководителем «Инквайри» считался советник президента полковник Э. Хауз. Директором бюро был назначен сначала Сидней Мезес, президент одного из нью-йоркских колледжей, а затем - Исайа Боумэн, глава американского географического общества. Определяя главную задачу создаваемой организации, Вильсон в письме Э. Хаузу подчеркнул необходимость «настраивать свои дудки» для подготовки американских предложений по послевоенному урегулированию «с полным знанием позиции всех воюющих сторон» [WW to E.M.; Хауз, с. 122]. Используя академический потенциал страны для конкретизации своих планов, Вильсон надеялся получить действительно «научные» по своему характеру рекомендации относительно создания нового миропорядка. Примечательно, что для него сам термин «научный миропорядок» был практически синонимом провозглашенного им принципа «мир без победы» [Link, p. 268; Wimer, p. 147; Gelfand The American... p. 192].

Всего за год с небольшим, когда работало «Инквайри», к его деятельности было привлечено до 150 ученых - историков, юристов, экономистов, этнографов и др. По преимуществу это были представители северо-восточных университетов. Средний возраст специалистов составил всего лишь 40 лет, а некоторым ведущим сотрудникам организации едва исполнилось 30. К числу последних можно отнести, например, Роберта Лорда, профессора Гарвардского университета; Сэмюэля Моррисона, преподавателя того же университета; Роберта Кернера, преподавателя университета Миссури; Чарльза Сеймура, профессора Йельского университета; Престона Слоссона, ассистен- 
та Колумбийского университета [0 персональном составе «Инквайри» см.: Gelfand The Inquiry... p. 53-68].

Руководство «Инквайри», в соответствии с инструкциями президента, предполагало изучить представления великих держав о политике по отношению к другим странам. Ставилась задача вооружить делегацию США на предстоящей мирной конференции необходимой фактической и аналитической информацией, конкретными альтернативными вариантами решения территориальных и иных споров, создания механизма международного урегулирования конфликтов, сокращения вооружений и т.д. [S.E. Mezes to WW] Итогом работы «Инквайри» стала подготовка почти 2000 докладов по различным проблемам, 1200 карт. Чтобы представить характер материалов, подготовленных экспертами, приведем некоторые цифровые данные, имеющиеся в монографии Л. Гельфанда. В архивах «Инквайри», по его подсчетам, сохранилось 894 различных документа, связанных только с вопросами европейского урегулирования. Из них 174 были посвящены Германии, 140 - Австро-Венгрии, 159 - Балканам, 203 - России и балтийским государствам, 158 - Западной Европе, 60 - нейтральным странам. Если детализировать, то, например, из докладов экспертов «Инквайри» по германской проблеме 4 включали так называемые первичные документы, 5 являлись историческими справками, в 10 были даны оценки политической ситуации и государственного устройства, 5 были посвящены вопросам границ, 1 - системе образования, 1 - колониям, 1 пангерманизму, 1 - состоянию общественного мнения, 1 - милитаризму, 30 - торговле и тарифам, 3 - Шлезвигу, 1 - Ютланду, 46 - Эльзас-Лотарингии, 1 - социальному благосостоянию, 2 - животным и лесным ресурсам, 14 - финансам и послевоенному экономическому положению, 1 - вопросу об ответственности за войну, 7 - общей политической и экономической ситуации в 1918 г., 9 - промышленности, 5 - торговому флоту; 26 документов имели смешанную проблематику [Gelfand The Inquiry... p. 110, 184-186]. Как видим, рассмотрение охватывало самый широкий спектр материалов по различным аспектам внутриполитического, экономического и международного положения. Все это должно было помочь американскому руководству располагать необходимой информацией для принятия решений на Парижской мирной конференции.

На какой внешнеполитической философии строили свой анализ сотрудники «Инквайри»? Большинство из них в целом разделяли вильсоновскую концепцию нового миропорядка. В частности, уже упоминавшийся профессор Д. Шотуэлл, возглавивший один из отделов новой организации, был убежденным сторонником либерального интернационализма. Он считал, что США должны нести меру ответственности за мир, отстаивая повсеместно принципы справедливости [Josephson, p. 76].

Рассмотрим некоторые суждения Д. Шотуэлла по поводу внешнеполитических аспектов вильсонизма. В своих мемуарах историк указывал прежде всего на созидательный характер программы президента США. «В то время, когда моральные силы человечества оказались на исходе, именно он [Вудро Вильсон. - B.P.] сумел пробудить их к жизни. ... В темные часы разочарования он увлек цивилизацию от бесполезного участия во всемирном разрушении к задаче, связанной не с перестройкой старой структуры, а с созданием нового мирового сообщества, о котором человечество даже и не 
мечтало». Определяя суть предложений В. Вильсона, Д. Шотуэлл указывал не только на его намерение добиться для США мирового лидерства, но и на морализм всей его внешнеполитической философии. Президент США, не желавший повторения Священного союза или универсальной империи, разработал программу, основанную на новой для мирового сообщества концепции, которая на деле означала всего лишь «глобализацию доктрины Монро». Все это, как считал Шотуэлл, стало настоящей «дипломатической революцией» [Shotwell, p. 20-25].

Самым существенным документом, подготовленным в «Инквайри» к январю 1918 г., стал меморандум «Современный момент: цели войны и вытекающие отсюда условия мира». Ситуация к этому времени (наметившиеся перспективы окончания войны, революция в России и др.) требовала выдвижения серьезной внешнеполитической инициативы, которая определила бы направленность программы США по послевоенному мирному урегулированию. Уолтер Липпман, один из руководителей «Инквайри», в беседе с Вильсоном так обрисовал смысл американских предложений: необходимы «условия мира, на которые со временем могли бы согласиться и сами немцы». Вместе с тем и В. Вильсон, и Э. Хауз, обсуждая суть американской программы, подчеркивали, что важнейшей целью ее должно стать соблюдение национальных интересов США [Печатнов, с. 79]. Содержание указанного меморандума представляется чрезвычайно важным, поскольку в нем, по сравнению с официальными «14 пунктами», более полно раскрывается политико-стратегическая подоплека американской программы. Кроме того, данный меморандум был первым серьезным документом, представленным от имени коллектива ученых для нужд Белого дома. Можно предположить, что именно в нем нашли отражение внешнеполитические представления, распространенные в той части академического сообщества, которая была ближе всего к идеологии вильсонизма.

В качестве цели как войны, так и мира меморандум определял «демонтаж прусской срединной Европы», т.е. исключение самой возможности доминирования германского милитаризма, являвшегося, по сути, главной угрозой национальной безопасности США. В связи с этим предполагалась демократизация Германии. В документе оговаривалась и опасность чрезмерного унижения Германии, что привело бы к господству реваншистских настроений в стране. Главным рычагом внешней политики Соединенных Штатов по отношению к Германии назывались экономические меры. Относительно России документ рекомендовал американской администрации занять примирительную позицию, для того чтобы попытаться сохранить ее в качестве союзника, «облагородив» цели войны. Политические взаимоотношения со странами Западной Европы должны опираться на либеральные круги Франции и Великобритании. Западные союзники, по словам составителей меморандума, должны быть подкреплены: «1) энергичным высказыванием в пользу экономического единства и контроля; 2) либеральным дипломатическим наступлением США, которое указало бы либералам в Великобритании и Франции путь к восстановлению национального единства во внешнеполитических целях; ... 3) подъемом интереса к войне и ее итогам со стороны американского народа». Лига Наций, в основу которой мог быть положен антигерманский союз, должна была стать краеугольным камнем всего мирного урегулирования. «Должна ли эта Лига 
быть вооруженной и не включающей в свой состав теперешних противников или, наоборот, разоруженной и дружественно включающей в себя Германию, зависит от того, будет ли германское правительство фактически представлять германскую демократию» [A Memorandum...].

Вильсон впоследствии принял большую часть рекомендаций «Инквайри», затушевав наиболее спорные территориальные вопросы и усилив общедекларативную часть в своем послании Конгрессу от 8 января 1918 г.

В дальнейшем специалисты из исследовательской организации продолжили активную детальную разработку наиболее существенных проблем мирного урегулирования. На наш взгляд, позиция представителей академических кругов в этих условиях отличалась серьезным научным подходом к определению перспективных ориентиров американской внешней политики.

Вот как, например, оценивались специалистами самые важные проблемы европейской ситуации - российская и германская. В качестве одного из экспертов по русскому вопросу в 1918 г. выступал выходец из России, профессор экономической истории Колумбийского университета Владимир Симкович. Э. Хауз в одном из писем Вильсону назвал его «наиболее информированным русским из числа тех, кого я знаю» [E.M. House to WW]. В своих меморандумах на имя У. Липпмана В. Симкович постоянно отстаивал необходимость восстановления полноценных взаимоотношений с новым большевистским правительством. По его мнению, позиции большевиков в России были на самом деле прочнее, чем их представляли на Западе. Находясь у власти, большевики могли бы стать более надежными союзниками Антанты, чем белогвардейцы, готовые отдать Германии все что угодно ради расправы над революцией. Симкович полагал, что впоследствии большевистский режим неизбежно стал бы более умеренным. Следовательно, нужно не бороться с новой российской властью, а помогать народам России [Печатнов, С. 84-85].

Другой документ - меморандум руководителя экономического отдела «Инквайри» А. Юнга, профессора экономики Корнельского университета. Высказывая соображения относительно репарационного вопроса, Юнг особо подчеркнул, что в основе репарации должен лежать учет только реального ущерба от войны, который требует «возмещения, а не наказания» [Gelfand The Inquiry... p. 297].

Как видим, эти точки зрения отличались большей взвешенностью от той политики, которую позднее будет проводить правительство Соединенных Штатов. Хотя и они, естественно, не отражали в полном объеме всех суждений по русскому и германскому вопросам, которые были высказаны различными экспертами.

Зачастую сотрудники «Инквайри» отстаивали в представляемых материалах противоположные точки зрения. Например, Роберт Кернер (университет Мичигана) в своих докладах, посвященных национальным проблемам в Центральной и Восточной Европе, настойчиво обосновывал концепцию «федерализации» Австро-Венгрии. По его 
мнению, все народы, проживавшие на ее территории, и прежде всего славяне, должны были получить полную автономию. Одновременно Р. Кернер выступал против максимального применения в этом регионе принципа самоопределения наций, поскольку создание крошечных национальных государств привело бы всего лишь к борьбе великих держав за доминирование над ними. А вот Чарльз Сеймур (Йельский университет) предлагал реализовать в послевоенной Австро-Венгрии концепцию «триализма», предоставив третью полноправную роль в государстве полякам. В меморандумах «Инквайри» обсуждались и другие варианты решения данной проблемы, но все специалисты вплоть до окончания войны, как правило, исходили из целесообразности сохранения единства империи [lbid, p. 200-203].

Материалы, подготовленные сотрудниками «Инквайри» по отдельным проблемам, проходили тщательное рецензирование. Иногда комментарии содержали крайне негативную оценку тех или иных выводов. Именно альтернативность суждений следует назвать главным достижением новой консультативной организации. Противоположные мнения по различным аспектам мироустройства давали политическому руководству США более целостное представление о реальной международной ситуации и, таким образом, позволяли принять более взвешенное решение. Думается, что такой вариант работы научных экспертов является наиболее приемлемым при разработке внешнеполитической стратегии любого государства.

Проблемы нового миропорядка и, в частности, перспективы создания международной организации обдумывались и теми представителями академического сообеества, которые не были официально приобщены к деятельности «Инквайри». На страницах американских газет и журналов конца 1917 - начала 1919 г. можно найти огромное количество разнообразных суждений на этот счет. Интересны, например, мнения таких известных американских ученых, как Торстейн Веблен или Фредерик Тернер [Veblen; Terner]. Анализируя политические аспекты нового миропорядка, они высказывались фактически за придание новой международной организации статуса наднациональной структуры, обладавшей законодательной властью. Закономерным продолжением была идея Ф. Тернера о создании международных политических партий, которые в перспективе стали бы своеобразным связующим звеном мирового сообщества [Подробнее см.: Романов, с. 266-273]. Значительная часть академического сообщества стремилась углубить вильсоновский интернационализм, который, по справедливой оценке ряда историков, в целом не смог все же преодолеть традиций «викторианского либерализма XIX века» [Mayer, p. 83; Herman, p. 174].

Другое направление интернационализма было представлено Н. Батлером. Его внешнеполитическая концепция, рассмотренная выше, в 1918-1919 гг. не претерпела каких-либо серьезных трансформаций. Он по-прежнему призывал к развитию международного сотрудничества во имя «прочного мира». Н. Батлер, например, неоднократно акцентировал внимание американцев на необходимости решительной борьбы против любого государства, стремившегося к мировому доминированию. Для «готовности страны и к миру и к войне» он призывал не только иметь сильные вооруженные силы, но и развивать американскую систему образования [Butler Program of Constructive... 
p. 49-50; Butler The Road to... p. 119]. Важным механизмом поддержания мира Н. Батлер по-прежнему считал международную организацию и поэтому в целом поддерживал действия президента Вильсона по созданию Лиги Наций. Но при этом он высказывался все же за постепенность начавшихся глобальных интеграционных процессов. В одной из статей, подготовленной в декабре 1918 г. для одновременной публикации в Echo de Paris и лондонской газете Observer, Батлер заявлял, что в современных условиях Лига пока что не должна превратиться в «международное правительство». По его мнению, следовало бы очень осторожно относиться к любым попыткам ограничения суверенитета национальных государств. Структура Лиги в его представлениях ассоциировалась всего лишь с кристаллическим образованием, в котором существует «определенным образом организованное единство полностью независимых элементов» [Butler American Opinion... p. 135, 137-138]. Словом, и на этом этапе Батлер занимал в американской внешнеполитической мысли своеобразное срединное место. Как видно из источников, он отдавал должное не только интернационализму В. Вильсона, но и его критикам, высказывавшим свои опасения по поводу дееспособности новой международной организации.

Представители академического сообщества внесли вклад не только в теоретическое осмысление послевоенного миропорядка, но и в дело его практического создания. Большая группа ученых, главным образом сотрудничавших с «Инквайри», выехала вместе с В. Вильсоном в Париж. Во время работы мирной конференции они не только принимали активное участие в подготовке экспертных заключений по тому или иному вопросу, но и были задействованы в различных комиссиях. Потенциал научных консультантов достаточно высоко оценивался современниками. Так, английский дипломат Г. Никольсон отмечал в своих воспоминаниях, что американская консультативная группа отличалась серьезным профессионализмом. «Я никогда не работал с людьми столь искусными, столь образованными и со столь широким кругозором или столь точно информированными, какими были американские делегаты на мирной конференции, - писал он. - ... Если бы мирный договор составляли исключительно американские эксперты, он был бы самым мудрым и самым научным из документов, какие когда-либо были написаны» [Никольсон, с. 41].

Многие существенные разработки академических кругов во время мирного урегулирования так и не были учтены, поскольку чаще всего над научным анализом превалировала тогда политическая конъюнктура. Тем не менее в отдельных случаях позиция, занимаемая американскими экспертами, оказывала значительное влияние на итоговые решения мирной конференции.

Рассмотрим, например, ход обсуждения в Париже вопроса о международном регулировании условий труда и о создании для этой цели соответствующей организации. Конференция сформировала специальную комиссию, которой было поручено подготовить предложения на этот счет. Возглавил ее председатель Американской федерации труда Сэмюэль Гомперс. Однако ему фактически не удалось достичь консенсуса с европейскими профсоюзными деятелями [О внешнеполитической позиции С. Гомперса см.: Листиков, с. 79-92; Shotwell, p. 54-56], и поэтому еще до окончания работы комиссии 
он уехал в США. Руководство комиссией перешло тогда в руки английского представителя Джорджа Барнса, а из числа американцев значимую роль в ее дальнейшей работе сыграл сотрудник «Инквайри», профессор Колумбийского университета Джеймс Шотуэлл.

Д. Шотуэлл, как и многие другие либералы, находился под влиянием революционных событий в Европе, прежде всего в России. Анализируя причины, приведшие, в частности, большевиков к власти, Шотуэлл указывал и на нежелание старых российских властей серьезно заниматься решением рабочего вопроса. Прибыв в Париж, он представил свой меморандум, в котором высказал предложения относительно путей достижения «социальной справедливости» в рамках мирного урегулирования. Без этого, отметил профессор, «всеобщий мир был невозможен». Совершенствование взаимоотношений между трудом и капиталом помогло бы международному сообществу приступить к «реализации наиболее фундаментального из всех принципов нового политического и социального устройства мира». Данный шаг он оценивал как «начало сотрудничества между Трудом, Обществом и Государством» [Shotwell, p. 54-56].

Среди рабочих лидеров, принимавших участие в Парижской конференции, существовали серьезные разногласия по конкретной программе возможных действий. Французы, например, настаивали на включении в мирный договор «хартии труда», которая предусматривала бы немедленное осуществление в международном масштабе таких реформ, как введение восьмичасового рабочего дня, установление минимального возраста для работы в промышленности. А представители Великобритании предлагали ограничиться на первом этапе для разрешения вопросов труда созданием особого международного механизма, который носил бы координационный характер. Д. Шотуэлл высказался в поддержку английского подхода, указав на важность объединения в рамках новой организации рабочих представителей с официальными представителями правительств отдельных стран. В этом он видел некий прообраз «мирового государства, которое находилось бы под эгидой индустриальной демократии и международного парламента труда». При этом Д. Шотуэлл высказал сомнения в целесообразности немедленного наделения международной организации труда законодательными функциями и придания ее решениям обязательного статуса для исполнения во всех государствах-членах Лиги Наций. В таком варианте он увидел опасность подрыва американской конституции. Предложения, сформулированные Шотуэллом, сводились к закреплению за данной организацией права вырабатывать рекомендации, что позволило бы мировому общественному мнению влиять на ход принятия в отдельных странах необходимого социального законодательства. В этом Д. Шотуэлл увидел существенную инновацию и очередной шаг на пути к всеобщему признанию идеи ограничения национального суверенитета в пользу международной организации [lbid, p. 54-59].

В итоге Парижская конференция приняла решение о создании Международной организации труда (МОТ). Ее статут, вошедший в текст послевоенных договоров, в целом основывался на англо-американской концепции [См.: Версальский мирный договор, с. 157-168], которая, как видим, была разработана при непосредственном участии 
Джеймса Шотуэлла. Сам он не раз повторял, что создание МОТ следует отнести к важнейшим итогам мирного урегулирования. Показательно, что в дальнейшем Д. Шотуэлл продолжал сотрудничать с новой организацией. Он, например, представлял Соединенные Штаты в оргкомитете международной рабочей конференции, проводимой в Вашингтоне в октябре 1919 г. [Shotwell, p. 54, 199-200; Josephson, p. 93-94]

Сознавая потребность расширения международного сотрудничества в условиях послевоенного миропорядка, Д. Шотуэлл понимал и все трудности, с которым встретится мировое сообщество на этом пути. В частности, вызывает интерес еще один меморандум, подготовленный американским профессором в Париже. В нем он высказал свои суждения по поводу возможного отказа какой-либо страны вступить в Лигу Наций. Для таких стран Д. Шотуэлл предлагал предусмотреть в новой организации особый статус, который предполагал бы их участие в международных конференциях по отдельным вопросам, например, по рабочему законодательству, разоружению или торговле. Текст предложенной им поправки к Ковенанту гласил: «Государства, не являющиеся членами Лиги, могут получить ассоциированное членство во время работы периодических конференций, проводимых под покровительством Лиги. Эти ассоциированные государства не принимают на себя какие-либо обязательства в связи с решениями конференции, на которой они присутствовали» [Shotwell, p. 230-233, 240-245]. Другими словами, данное предложение можно рассматривать как некий компромиссный вариант для тех, кто пока что не желал принимать в полной мере концепцию интернационализма. Даже ограниченное участие в делах мирового сообщества, по мнению Д. Шотуэлла, все равно стало бы первым шагом на пути к новому универсальному миропорядку. Данное предложение так и не было рассмотрено в Париже, о чем Шотуэлл с сожалением писал в своих мемуарах [lbid, p. 190, 301-306]. Зато идею ассоциированного членства взяла на вооружение Международная организация труда.

Как и другие американские либералы, Д. Шотуэлл впоследствии не раз указывал на слабые стороны созданного в Париже миропорядка. Его главный порок он видел в том, что государства-победители отказались тогда вести переговоры с побежденными. Действительно единое мировое сообщество построить не удалось. К сожалению, заключал профессор, мир через диктат был, скорее всего, неизбежен в условиях послевоенной Европы, да и мира в целом. Ряд ошибок В. Вильсона Д. Шотуэлл связывал с особенностями его политической философии. Президент, по словам Шотуэлла, надеялся, что новые условия мироустройства, сформулированные в соглашении о Лиге Наций, исправят все недостатки старого мира. Но Вильсон оказался «не в состоянии увидеть, что процесс исправления нельзя было откладывать, поскольку это ослабило бы Лигу и, в конечном счете, поставило бы под угрозу само ее существование» [lbid, p. 41-42, 51].

Несмотря на то, что Д. Шотуэлл высказывал свое несогласие с рядом решений Парижской конференции, в целом он не осуждал послевоенного урегулирования. Более того, он приветствовал рождение международной организации. Тем самым он отличался от других интернационалистов из американского академического сообщества, 
которые зачастую акцентировали внимание на негативных сторонах и Лиги Наций, и всего Версальского миропорядка [Josephson, p. 96].

Участие американских ученых в Парижской мирной конференции действительно способствовало тому, что академическое сообщество превратилось в постоянный и существенный фактор процесса принятия внешнеполитических решений. Осознав это, научная элита попыталась создать собственный механизм для координации усилий в области изучения международных отношений. Показательно, что первые предметные разговоры на этот счет велись в Париже не только американцами, но и представителями других стран. 30 мая 1919 г. в отеле «Маджестик» произошла важная встреча, на которой присутствовали И. Боумен, Дж. Бир, Дж. Шотуэлл (все они были сотрудниками «Инквайри»), Т. Ламонт - крупный банкир, выступавший на конференции в роли экономического советника делегации США, Р. Сесиль - известный политический деятель Великобритании, Л. Куртис - научный консультант английской делегации и другие представители политико-академического истеблишмента двух стран. Осознавая порочность многих положений мирного урегулирования, они вели тогда речь о необходимости более научного подхода к определению перспектив международного развития. Главным результатом их беседы стало решение об учреждении англо-американского Института международных отношений. Именно этот Институт, объединивший авторитетных ученых, политиков, финансистов и промышленников, положил начало действующему по сей день Совету по международным отношениям [From the Peace...; Shotwell, p. 346; Schulzinger, p. 3-7]. Любопытно, что на американских ученых сделала серьезную ставку в ту пору и Франция. По инициативе Парижа была расширена практика научных обменов. В 1921 г. 265 американцев были привлечены к работе в высших учебных заведениях Франции. (Для сравнения: накануне войны, в 1914 г., из США с этой же целью были приглашены всего 54 человека.) Все эти контакты не без оснований рассматривались тогда как существенный канал влияния на европейских союзников [Keylor, p. 363].

Академическое сообщество США внесло весомый вклад в оформление официальных решений. Выступая в качестве экспертов, ученые сумели расширить границы внешнеполитического мышления и информационного поля, в рамках которого действовал Белый дом. Этому способствовали, прежде всего, регулярно готовившиеся ими для президента меморандумы по отдельным аспектам американской дипломатии. Свою роль сыграли также разнообразные исследовательские и даже популярные материалы, которые издавались в виде книг и статей. Самые интересные публикации, как показывают источники, обязательно привлекали внимание американского президента. Апогеем использования академического потенциала для внешнеполитических нужд администрации Вильсона можно считать создание и деятельность первой в истории Соединенных Штатов солидной научно-исследовательской группы по подготовке программы послевоенного урегулирования.

Именно эта практика во многом заложила основы для дальнейшего формирования экспертного планирования внешней политики США. 
Показательным был идейный арсенал, который использовало большинство американских ученых периода Первой мировой войны. В своих суждениях они, как правило, исходили из концепции либерального интернационализма, ставшего новым вектором внешней политики США. Однако их интернационализм базировался на традиционных представлениях политико-академической элиты Соединенных Штатов об «американской исключительности», что предполагало безоговорочное лидерство США в новом мире.

\section{Литература}

Архив внешней политики Российской империи (АВПРИ). Ф. 170. Оп. 512/1. Д. 341. Л. 105-106. Версальский мирный договор. М. 1925.

Дмитриев А.А. Мобилизация интеллекта: Первая мировая война и международное научное сообщество // Интеллигенция в истории: образованный человек в представлениях и социальной действительности. М. 2001.

Дьяков А.В. Политическая функция интеллектуала: история и современность // Полис. Политические исследования. 2019. № 1. С. 21-32.

Листиков С.В. Профсоюзное движение США в годы Первой мировой войны. М.1987. Мировые войны XX века: В 4 кн. М. 2002. Кн. 1: Первая мировая война: Исторический очерк. Никольсон Г. Как делался мир в 1919 г. М. 1945.

Основы прочного мира. Статьи Cosmos'a, появившиеся в Нью-Йоркском Times. N.Y. 1917.

Первая мировая война и судьбы европейской цивилизации / Под ред. Л.С. Белоусова, А.С. Маныкина. М. 2014.

Первая мировая война: Исторический очерк. С. 127.

Петровский В.Ф. Внешнеполитическая мысль США. М. 1976.

Печатнов В.О. Уолтер Липпман и пути Америки. М. 1994.

Романов В.В. «Академический» интернационализм: проблема наднациональных политических институтов в проектах Т. Веблена и Ф. Тернера накануне Парижской мирной конференции 1919 г. // Первая мировая война, Версальская система и современность: сб. статей / отв. ред. И.Н. Новикова, А.Ю. Павлов, А.А. Малыгина. СПб. 2014.

Тексты воззвания «К культурному миру» и меморандума С.Г. Черча цитируются по русскому изданию: Америка о войне. Ответ на воззвание германских профессоров. Пг. 1915.

Хауз Э. Архив полковника Хауза. [Дневники и переписка с президентом Вильсоном и др. полит. деятелями] / Подгот. к печати проф. истории Иэйлского ун-та Чарлзом Сеймуром. М. 1939. T. 3.

A Memorandum by S.E. Mezes, D.H. Miller, and W. Lippmann. The Present Situation: The War Aims and Peace Terms It Suggests. [c. Dec. 22, 1917] // PWW. Vol. 45. P. 459-473.

An Address in Washington to the League to Enforce Peace. May 27, 1916 // The Papers of Woodrow Wilson / Ed.: A.S. Link et al. Vol. 1-69. Princeton. 1966-1994 (далее - PWW). Vol. 37. P. 113-116.

Butler N.M. A Program of Constructive Progress. An Address Delivered before the Commercial Club. St. Louis, Missouri. Feb. 16, 1918 // Butler N.M. Is America Worth Saving? Addresses on National Problems and Party Policies. L.1920.

Butler N.M. American Opinion and Problems of Peace. A Statement published in «Echo de Paris» Dec. 5, 1918 and in London «Observer» Dec. 8, 1918 // Butler N.M. Is America Worth Saving? Addresses on National Problems and Party Policies. L.1920. 
Butler N.M. The Road to Durable Peace. An Address Delivered before the Chamber of Commerce. St. Louis, Missouri. Feb. 16, 1918 // Butler N.M. Is America Worth Saving? Addresses on National Problems and Party Policies. L. 1920.

Ch. Eliot to Woodrow Wilson (далее - WW). Aug. 6, 20, 1914 // PWW. Vol. 30. P. 353-355, 418-420.

Ch. Eliot to WW. July 16. 1915 // PWW. Vol. 33. P. 513-515.

Ch. Eliot to WW. July 26. 1915 // PWW. Vol. 34. P. 30.

D.S. Jordon to WW. March 19. 1913 // PWW. Vol. 27. P. 195.

E.M. House to WW. Apr. 20. 1917 // PWW. Vol. 42. P. 111.

E.M. House to WW. Nov. 21. 1916 // PWW. Vol. 40. P. 30.

From the Peace Conference Diary of G.L. Beer. June 1, 1919 // PWW. Vol. 60. P. 17.

G.W. Kirchwey to WW. July 15. 1915 // PWW. Vol. 34. P. 15-16.

Gelfand L.E. The American Mission to Negotiate Peace: An Historian Looks Back // The Treaty of Versailles: A Reassessment after 75 Years / Ed. by M.F. Boemeke, G.D. Feldman, E. Glaser. Washington-Cambridge. 1998.

Gelfand L.E. The Inquiry: American Preparation for Peace, 1917-1919. New Haven.1963.

H. Münsterberg to WW. Nov. 7, Nov. 19. 1914; Apr. 19, 1915 // PWW. Vol. 31. P. 276-278, 336-340; Vol. 33. P. 17-20.

Herman S.R. Eleven against War: Studies in American Internationalist Thought, 1898-1921. Stanford. 1969.

J.H. Hollander to WW. Apr. 7. 1913 // PWW. Vol. 27. P. 265.

J.P. Tumulty to WW. Nov. 21. 1916 // PWW. Vol. 40. P. 24.

Josephson H. James T. Shotwell and the Rise of Internationalism in America. L. 1975.

Keller Ph. States of Belonging. German-American Intellectuals and the First World War. Cambridge. 1979.

Keylor W.R. «How They Advertised France»: The French Propaganda Campaign in the United States during the Breakup of the Franco-American Entente, 1918-1923 // Diplomatic History. Vol. 17, № 3 (Summer 1993).

Knock T.J. To End All Wars: Woodrow Wilson and the Quest for a New World Order. N.Y., Oxford. 1992.

Kuehl W.F. Seeking World Order. The United States and International Organization to 1920. Nashville. 1969.

Link A.S. Wilson: Campaign for Progressivism and Peace, 1916-1917. Princeton.1965.

Mayer A.J. Historical Thought and American Foreign Policy in the Era of the First World War // The Historian and the Diplomat. The Role of History and Historians in American Foreign Policy / Ed. by F.L. Loewenheim. N.Y. 1967.

Minor R.C. A Republic of Nations: A Study of the Organization of a Federal League of Nations. N.Y. 1918.

Münsterberg $H$. The Peace and America. Leipzig. 1915.

Münsterberg $H$. The War and America. Leipzig. 1915.

R.H. Dabney to WW. Jan. 1, 1915 // PWW. Vol. 32. P. 3.

Reinsch P. An American Diplomat in China. L. 1922.

S. Mathews to WW. Aug. 18, 1914 // PWW. Vol. 30. P. 396-398.

S.E. Mezes to WW. Nov. 9, 1917 // PWW. Vol. 44. P. 549-551.

Schulzinger R.D. The Wise Men of International Affairs. The History of the Council on Foreign Relation. N.Y. 1984. 
Shotwell J. T. At the Paris Peace Conference. N.Y. 1937.

T. Roosevelt to H. Münsterberg. Oct. 3, Nov. 2, 1914 // The Letters of T. Roosevelt. Vol. 8. Cambridge. 1954.

Terner F.J. A Memorandum. International Political Parties in a Durable League of Nations. Nov. [30?], 1918 // PWW. Vol. 53. P. 264-265.

The American Journal of International Law. Vol. 9. № 1 (Jan., 1915).

The Foreign Relations of the United States. A Series of Addresses and Papers Presented at the National Conference on Foreign Relations of the United States at Long Beach, May 28 - June 1, 1917 / Ed. by H. R. Mussey and S.P. Duggan // Proceedings of the Academy of Political Science. Vol. 7, № 2-3 (July 1917).

The Intellectual Response to the First World War: How the Conflict Impacted on Ideas, Methods and

Fields of Enquiry / Ed. M. Demoor, S.Posman, \& C. Van Dijck. Eastbourne. 2017.

The New Republic. Vol. 1. № 2 (Nov. 14, 1914).

The New Republic. Vol. 1. № 9 (Jan. 2, 1915).

The New Republic. Vol. 5. № 55 (Nov. 20, 1915).

The New York Times (NYT). Aug. 12. 1916.

The New York Times. Dec. 15, 18. 1916.

The New York Times. Dec. 15. 1916.

The New York Times. Dec. 2, 4. 1916.

The New York Times. Dec. 9. 1916.

The New York Times. Nov. 20. 1916.

The New York Times. Nov. 21, 22. 1916.

The New York Times. Nov. 25. 1916.

The New York Times. Nov. 27. 1916.

The New York Times. Nov. 28. 1916.

The New York Times. Nov. 30. 1916.

The North American Review. Vol. 198, № 6 (Dec., 1913).

Veblen T. An Inquiry into the Nature of Peace and the Terms of Its Perpetuation. N.Y. 1917.

Wimer K. Woodrow Wilson and World Order // Woodrow Wilson and a Revolutionary World, 19131921 / Ed. by A.S. Link. Chapel Hill.1982.

WW to E.M. House. Sept. 1, 1917 // PWW. Vol. 44. P. 120-121.

WW to R.C. Minor. Jan 5, 1915 // PWW. Vol. 32. P. 18.

WW to R.H. Dabney. Jan. 4, 1915 // PWW. Vol. 32. P. 10-11. 